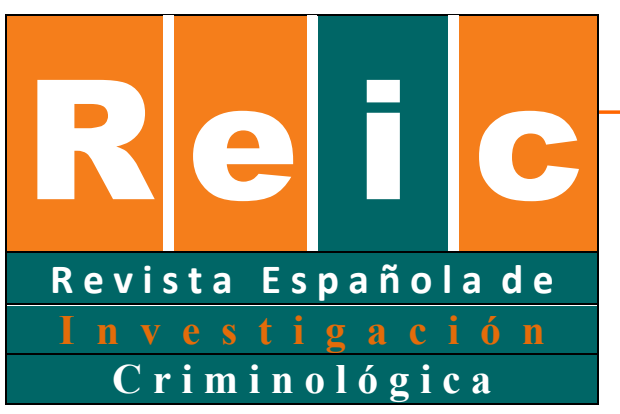

Papadopoulos \& van Buggenhout

\title{
Giving voice to migrant children during reception and asylum \\ procedures. Illustrations on the implementation of Art. 12 CRC \\ in Greece and Belgium
}

\section{Dar voz a los niños migrantes durante la recepción y los procedimientos de asilo. Ilustraciones sobre la implementación del art. 12 CRC en Grecia y Bélgica}

Ioannis Papadopoulos ${ }^{(D)} 1$

Institute of Criminal Justice Studies

University of Portsmouth, UK

Marijke van Buggenhout ${ }^{(D)}$

Voicing Youth at Social Risk Research Group and Crime and Society Research Group,

Vrije Universiteit Brussel, Belgium

\section{ABSTRACT}

According to a children's rights' approach, asylum-seeking children are entitled to special protection. However, reality dictates that as soon as they enter a host country irregularly, they are often criminalised, thus becoming part of the crimmigration debate and as a result they are further deprived of basic human rights including the right to be heard, as enshrined in the

\footnotetext{
${ }^{1}$ Corresponding author: 1. Ioannis Papadopoulos, Institute of Criminal Justice Studies, Faculty of Humanities and Social Sciences, University of Portsmouth, St. George's Building, 141 High Street, PO1 2HY Portsmouth UK. E-mail: ioannis.papadopoulos@port.ac.uk; 2. Marijke van Buggenhout, Vrije universiteit Brussel, Faculteit Recht \& Criminologie, Pleinlaan 2,1050 Elsene Belgium. E-mail: marijke.van.buggenhout@,vub.be.
}

Revista Española de Investigación Criminológica

Article 1, Volume 18(2) (2020)

https://doi.org/10.46381/reic.v18i2.347

www.criminologia.net

ISSN: 1696-9219 
UN Convention on the Rights of the Child. This paper starts from a discussion on the fact that children on the migratory pathway need to be granted a central and active role in research, especially in times when new theoretical concepts in the field of juvenile justice and migration policing are introduced. We continue by delving into both an illustration from Greece and Belgium on how the right of the child to participate and to be heard is applied during reception and asylum procedures. We draw attention to the existing peculiarities of rights-based research methods in immigration studies, whilst arguing for holistic approaches that aim to move beyond the decorative concept of voicing children and towards a positive change concerning asylum processes for migrant minors.

Keywords: UNCRC, migrant minors, immigration detention, crimmigration debate, asylum processes, right to be heard, migration policing, asylum interview.

\section{RESUMEN}

Según el enfoque de los derechos de la infancia, los niños, niñas o adolescentes solicitantes de asilo tienen derecho a una protección especial. No obstante, la realidad muestra que tan pronto como entran en un país de manera irregular, son criminalizados, convirtiéndose así en parte del debate sobre la crimigración. Como resultado, se ven privados de sus derechos humanos básicos, incluido el derecho a ser oídos, consagrado en la Convención de las Naciones Unidas sobre los Derechos del Niño. El presente artículo parte de una discusión sobre el hecho de que la infancia en movimiento requiere un papel central y activo en la investigación, especialmente en momentos en que se introducen nuevos conceptos teóricos en el ámbito de la justicia juvenil y la vigilancia migratoria. En segundo lugar, se profundiza, a través de los casos de Grecia y Bélgica sobre cómo se aplica el derecho del niño, niña o adolescente a participar y a ser escuchado durante los procedimientos de recepción y asilo. Se llama la atención sobre las peculiaridades existentes en los enfoques de investigación basados en derechos aplicados a los estudios sobre inmigración, y se aboga por el uso de enfoques holísticos que tengan como objetivo superar el concepto simbólico de dar voz a los niños, niñas y adolescentes y así conseguir un cambio positivo con respecto a los procesos de asilo de la infancia migrante.

Palabras clave: UNCRC, menores migrantes, detención migratoria, debate sobre la crimigración, procesos de asilo, derecho a ser oído, vigilancia migratoria, entrevista de asilo

\section{Introduction}

The issue of protecting the rights of children in an uninterrupted and legally effective way under the scope of the UN Convention on the Rights of the Child (1989, hereinafter CRC), has always been at the forefront of all contracting member States' national policies, despite the difficulties involved in its implementation process. For this reason, the need to provide

Revista Española de Investigación Criminológica

Article 1, Volume 18(2) (2020)

https://doi.org/10.46381/reic.v18i2.347

www.criminologia.net

ISSN: 1696-9219 
ample and adequate protection to those requiring substantial legal and procedural assistance gradually became a more pressing reality, especially due to the massive number of asylumseeking individuals arriving in Europe, including both unaccompanied minors (hereinafter UAM), as well as minors who are separated from their parents or legal guardians (UN High Commissioner of Refugees, 2013, hereinafter UNHCR; EKKA, 2019²). Nevertheless, even though children who migrate seem to have a very strong and undebated claim to protection and care according to protectionist rhetoric's (Bhabha, 2001), they often find themselves in situations of uncertainty, in-between-citizenship or even complete rightlessness.

Based on the above, socio-legal issues regarding migration control and policing gradually became matters of crucial importance in European societal debates in which discourses have evolved on migration and crime control imperatives. Subsequently, criminological science has shown a growing interest in the matter with the introduction of new theoretical concepts such as crimmigration, indicating the convergence and alignment of processes of criminal law enforcement and migration control (Stumpf, 2006; Aas, 2011; Aliverti, 2012; Pakes, 2013). The latter can be illustrated by the reported resemblances between immigration detention centres and prisons (Bosworth, 2014), the ambivalent political rhetoric on the dangerousness of migrants (Bhabha, 2014) as well as the normalisation of deportation, rendering the legal personhood of asylum seekers and undocumented immigrants precarious (Gündogdu, 2015, p. 18).

Asylum-seeking children in their majority, originate from countries which are severely affected by warfare activities and characterized by a clearly unstable and practically insecure socio-political and cultural regime. As a result, migrant minors often experience forced migration, coupled with extensive deprivation of human rights as depicted in the CRC, thus leading to phenomena of victimization. For this reason, children on the migratory pathway most commonly arrive in Europe in an effort to seek refuge far from persecution, which confirms the prerequisites of the refugee status as enshrined in Art. 1A of the Geneva Convention (1951, hereinafter Convention) and amended by Art. 1 (2) of the Protocol relating

\footnotetext{
${ }^{2}$ National Centre of Social Solidarity. Situation Update Unaccompanied Children Greece 31 August 2019. Available at https://reliefweb.int/report/greece/situation-update-unaccompanied-children-uac-greece-31-august-2019.
}

Revista Española de Investigación Criminológica

Article 1, Volume 18(2) (2020)

https://doi.org/10.46381/reic.v18i2.347

www.criminologia.net

ISSN: 1696-9219 
to the Status of Refugees (1967). Therefore, it has been widely supported both in the literature and research that asylum-seeking children are considered to be particularly vulnerable and in need of special protection and support upon arrival in European host countries (UN General Assembly, 1996; Goodman, 2004; Derluyn \& Broekaert, 2008; Thommessen, Laghi, Cerrone, Baiocco \& Todd, 2013; Thommessen, Corcoran \& Todd, 2015; Papadopoulos \& Pycroft, 2019). This would include processes that safeguard children's rights under the scope of the $\mathrm{CRC}$, both during reception proceedings (e.g. Vervliet, Rousseau, Broekaert \& Derluyn, 2015), as well as in the course of the asylum process (Papadopoulos, 2020).

However, despite the research that has been conducted on the issue of wellbeing and integration of migrant minors in Europe (e.g. Lidén \& Nyhlén, 2016), not much attention has been given to the right of asylum-seeking children to be heard throughout the administrative steps that follow their irregular entry and subsequent application for international protection. To this end, this paper places emphasis both to Greece and Belgium and further examines whether Art. $12 \mathrm{CRC}$, namely the children's right to participate, be heard and question all matters affecting them, is properly applied during reception and asylum procedures. In recent years, Greece has been widely referred upon both in literature and research for being the stepping-stone to international protection for most children on the migratory pathway. However, despite the plethora of regulations that protect and promote children's rights, the massive numbers of UAM arriving in Greece cause retributive migration policies to apply.

For this reason, this paper will initially add focus on the criminalisation of minors due to their irregular entry, the latter being a form of reactionary political response on the side of Greece as a host country, eventually causing migrant minors to be subjected to administrative proceedings that resemble criminal law processes (Papadopoulos \& Pycroft, 2019; Papadopoulos, 2020). On the other hand, this contribution raises the question what it means for children to be voiced in the asylum procedure in Belgium. We will use the case of the asylum interview in Belgium as an illustration of the importance of children's narratives and stories to prove credibility in the context of migration administration. The Belgian case is interesting as there is a child-specific approach to be found both in the legal framework as well as in daily practice where children under the age of twelve are being heard in child

\section{Revista Española de Investigación Criminológica}

Article 1, Volume 18(2) (2020)

https://doi.org/10.46381/reic.v18i2.347

www.criminologia.net

ISSN: 1696-9219 
specific hearing rooms by specialized Protection Officers. Hence, even though such childspecific provisions exist, there are still tensions to be observed between researching the susceptibility of a child's claim for international protection and the actual issue of protecting the rights of children's in this context.

By discussing the implementation of Art. 12 CRC in two different frameworks and two different stages of the reception process for migrant children, namely the administrative processes that follow their illegal entry in Greece and the actual asylum interview in Belgium, a link will be established between the right of children to be heard, as enshrined in Art. 12 CRC and its current applicability within the domestic policy of contemporary European member States. For this reason, in an effort to aim for holistic approaches that allow for the voice children on the migratory pathway to be heard, this paper looks through the lens of a children's rights approach and discusses the clear tension that exists between the best interest of the child principle, as introduced in Art. $3 \mathrm{CRC}$ and the need for migrant minors to be voiced during all stages of the asylum process in the host country. Based on the above and taking into consideration the special status of asylum-seeking children, their role in the crimmigration debate will also be discussed, as well as the need for them to be granted a central and active role in contemporary research. As a result, it is through combining perspectives from the disciplines of both law and criminology that allows for this paper to elaborate on the need for in-depth empirical analysis of children's rights in the context of migration, whilst moving beyond the tokenistic concept of voicing children (Lundy, 2007, p. 938) and towards an era of positive change with regard to asylum processes for children seeking a safe future out of harm's-way and certainly far from their country of origin.

\section{Researching the Right to be Heard in the context of migration}

In order to understand how human rights are enforced in the everyday reality of migrant children who arrive in Europe and undergo reception and asylum procedures and what effect these rights have in their lives, scholars need to find ways to access children's rights empirically, both on an implementation level, as well as on the level of lived experiences of

Revista Española de Investigación Criminológica

Article 1, Volume 18(2) (2020)

https://doi.org/10.46381/reic.v18i2.347

www.criminologia.net

ISSN: 1696-9219 
those who are subjected to both immigration enforcement and protection concerns. In what follows, we will discuss methodological peculiarities and the importance of rights-based research methods in immigration studies involving children. Even though rights-based research methods have been widely recognized, they still need thorough ontological, epistemological, theoretical and ethical reflections and critical examination in every research setting. Therefore, it is not only interesting to consider what it means for children on the move to be voiced in different contexts throughout reception and asylum procedures, but to also draw parallels on how voice and issues thereof are being remediated in social scientific research. In the past two decades, a paradigm shift has been established in the way participation of children in research has become central to academic inquiry (James, 2007; Powell, Fitzgerald, Taylor \& Graham, 2012; James \& Prout, 2015).

Under the impulse of the CRC came a movement away from the assumption that children are helpless and not capable of forming their views or making decisions on their behalf (Landsdown, 1994), towards being actively involved in reconstructing their livelihoods and development (James, Jenks \& Prout, 1998). These evolutions show that depending on how researchers look at children, performing research and producing knowledge is influenced accordingly (Kellett, Forrest \& Ward, 2004). According to James \& Prout (2015), child-based research implies that a more active role is adjudicated to children as capable actors and experts of their narratives. With this new paradigm came the need to rethink existent methodological and theoretical frameworks beyond voicing, in which reflections on the right to participation were omnipresent (Lundy, 2007). Hence, interdisciplinary theoretical perspectives on conducting research with children and young people have been developed, causing a conceptual transformation in which the voice of children is explicitly discussed (Munford \& Sanders, 2004; Powell \& Smith, 2006). To this end, children need to be granted the right to control their narrative in child-centred approaches, a goal which cannot always be achieved by more traditional in-depth interviews (Beazley, Bessell, Ennew, \& Waterson, 2010).

Even though methodological frameworks were formed and reformed over the years in a way that giving voice to children became central in research, we can say that the scientific

\section{Revista Española de Investigación Criminológica}

Article 1, Volume 18(2) (2020)

https://doi.org/10.46381/reic.v18i2.347

www.criminologia.net

ISSN: 1696-9219 
robustness continuously needs to be debated: A critical, reflexive approach to child-voice research needs to take into account the actual research contexts in which children's voices are produced and power imbalances that shape them. However, instead of detracting from the value of voice in research, acknowledging and reflecting on the situated character of children's voices and their limits can, potentially, contribute to new, more productive ways of producing and representing children's voices (Spyrou, 2011, p. 2). We would like to argue that obstacles, challenges and even failures in academic research create an important source of knowledge. A form of knowledge about voicing that can serve professional, institutional and practical contexts such as in this case reception and asylum procedures undergone by migrant children. Even though including voices of children has almost entirely become routine practice in research, Lundy, McEvoy \& Byrne (2011) stress the importance of taking a critical stance at the growing body of "voicing" scholarship. After all, the use of the concept voicing or children being voiced in the field of migration studies, without a further contextualization, can portray children as overly passive, to which end, it seems like a researcher is required to enable asylum-seeking children to express themselves without hesitation. For this reason, conceptual and epistemological pitfalls need to be discussed.

When conducting research with asylum-seeking children, there are several elements that make it more difficult to create open dialogues, such as language barriers, cultural differences, power imbalances and trust issues (Oh, 2012), especially in cases where the lack of trust leads to a clear unwillingness on the part of the child to participate in research (Hancilova \& Kanuder, 2011). An issue that is specifically pertinent and often discussed in research with vulnerable groups is the power imbalance between researcher and participant (Hood, Mayall, \& Oliver, 1999; Barker \& Smith, 2001; Christensen, 2004; Gallagher, 2008; Holland, Renold, Ross, \& Hillman, 2010; Hunleth, 2011). The power disparity is even harder to overcome in research with children as they are often considered to be relatively powerless compared to adults (Clacherty \& Donald, 2007; Morrow \& Richards, 1996). It has been stated that participatory research can partially restore power disparity (Thomas \& O'Kane, 1998). However, the philosophy behind the concept of participation cannot be generalized for all approaches of a participatory character. Within this line of thought, Hart (1997) points out

\section{Revista Española de Investigación Criminológica}

Article 1, Volume 18(2) (2020)

https://doi.org/10.46381/reic.v18i2.347

www.criminologia.net

ISSN: 1696-9219 
that several levels of participation need to be distinguished from one another: from a decorative form of participation to a collegiate process in which participants are consulted for all stages of the research process. Research can be collaborative, in the sense that children and researcher collaborate (co-research) during the phase of data collection, analysis and dissemination, but that it is still the researcher who stays in control of creating the research questions, describing the research goals and design. This way of doing research is still led by an adult, and not to be compared to child-led research approaches, where children determine the focus of exploration, choose the methods of investigation and actively disseminate their findings (Kellett, 2012, p. 7). Different forms of participation and collaboration can exist and can even be used complementary to each other. However, transparent communication about the level of participation is crucial to participatory research, to which end Lundy (2007, p. 938) supports the argument that often children are asked for their views and then not told what became of them; what is, whether they had any influence or not, thus warning us to be alert towards such decorative approaches of voicing research.

Based on the above, in an effort to provide children with the right to be heard and express their opinions freely concerning all matters affecting them, Art. 12(1) CRC establishes that the views of the child must be given due weight in accordance with the child's age and maturity, whereas according to Art. 12(2) CRC, children must have the opportunity to be heard in all judicial and administrative proceedings affecting them. According to Lundy (2007), Art. 12 CRC ensures that children are given opportunities to form and express their views in a free manner, whereas Krappmann (2010) argues that Art. 12 CRC encompasses the premise that although children cannot make decisions for themselves on many issues, they have the right to be heard and that have their views seriously considered when decisions are taken and when these decisions have an immediate effect on them. After all, the importance of children being able to participate actively in the decision-making process has been supported by McCafferty (2017, p. 330), stating that if children are not openhandedly provided with opportunities to express themselves freely or participate actively within the decision-making process about the matters that affect them, this would represent a direct contradiction to safeguarding a human-rights-based perspective. And for the latter to be

\section{Revista Española de Investigación Criminológica}

Article 1, Volume 18(2) (2020)

https://doi.org/10.46381/reic.v18i2.347

www.criminologia.net

ISSN: 1696-9219 
achieved, the UN Committee on the Rights of the Child (hereinafter Committee) supports that it is not necessary that the child has complete knowledge of all aspects of the matter affecting her or him, but that she or he has sufficient understanding to be capable of appropriately forming her or his own views on the matter (2009, para. 21), thus indirectly suggesting that for children to be able to form and express a view freely, Art. 12 CRC must be read in light of Art. $13 \mathrm{CRC}$, that is, the right of all children to seek, receive, and impart information (Lundy, McEvoy \& Byrne, 2011).

Furthermore, about the more judicial Art. 12(2) CRC in specific, the Committee (2009, para. 32-33) supports that this provision applies to all relevant judicial proceedings affecting the child, without limitation, including, among others, criminal law cases, as well as cases affecting asylum-seeking and refugee children, proving that Art. $12 \mathrm{CRC}$ is both a substantive right, as well as a procedural right in relation to the other CRC provisions. Following this premise and taking into consideration the legal and procedural perils that exist during the implementation process of Art. $12 \mathrm{CRC}$, it has been supported in the literature that the right to be heard should always apply when it comes to children on the migratory pathway being subjected to reception and asylum proceedings (Hodgkin \& Newell, 2007; Parkes, 2013; Rap, 2019, p. 10). Hence, stemming from the difficulties that are involved with regard to the applicability of Art. 12 CRC both upon the minors' illegal entry in European host countries, as well as throughout the followed international protection processes, we will now focus on the implementation of the right to be heard within the Greek and Belgian context, under the scope of the CRC

\section{On questioning criminalisation processes in Greece}

Even though illegal entry in a European host country could be the basis of a plethora of discussion topics in the field of immigration law and policing, the applicable law in Greece remains rather straightforward regarding the issue at hand. In detail, according to the Greek law, no differentiation whatsoever exists among asylum-seeking individuals when it comes to administrative processes following their illegal entry in the country (Papadopoulos \& Pycroft, 2019). More specifically, to enter the country irregularly is considered to be in direct

\section{Revista Española de Investigación Criminológica}

Article 1, Volume 18(2) (2020)

https://doi.org/10.46381/reic.v18i2.347

www.criminologia.net

ISSN: 1696-9219 
violation of Art. 83(1) of Act 3386 of 2005, according to which a third-country national who leaves or attempts to leave or enters or attempts to enter the Greek territory without legal formalities shall be punished by imprisonment of at least three months and a penalty of at least EUR 1,500. Hence, the specific point in time that is of crucial importance is when one attempts to, or successfully manages to enter the Greek territory irregularly because this is when one is arrested, and legal charges are pressed.

As a result, a standardised criminalisation of illegal entry occurs, despite the existing guarantees of the right to asylum of Art. 18 of the Charter of Fundamental Rights of the European Union (2012), clearly stating that The right to asylum shall be guaranteed with due respect for the rules of the Geneva Convention of 28 July 1951 and the Protocol of 31 January 1967 relating to the status of refugees and in accordance with the Treaty establishing the European Community. Adding to the above, the administrative steps following the illegal entry of asylum-seeking children in Greece, include them being temporarily placed under custody of a protective character, until they are identified as minors and then assigned either to legal guardians, or humanitarian organization (Papadopoulos, 2020). However, due to the inability of the Greek State to cover the needs of the excessively high number of migrant minors irregularly arriving in the country, protective custody is often replaced by proceedings that resemble detention (Papadopoulos \& Pycroft, 2019). The latter causes a unique procedural phenomenon where asylum-seeking children are placed in detention facilities, pending referral to appropriate hosting units, as soon as all administrative procedures are completed.

However, research has shown that detention in this case leads to children being subjected to conditions that are highly inappropriate (Greek Ombudsman, 2003-2011, 2016; Galante, 2014; Papadopoulos, 2020) and challenges Art. 3 CRC (Papadopoulos \& Pycroft, 2019), as discussed. This argument has also been widely supported by several human rights instruments (UN Human Rights Council Report of the Working Group on Arbitrary Detention 2015, para. 46; UN Committee on the Protection of the Rights of all Migrant Workers and Members of their Families 2017, para. 32), stating that the deprivation of liberty of asylum-seeking children, including unaccompanied or separated children, as well as

Revista Española de Investigación Criminológica

Article 1, Volume 18(2) (2020)

https://doi.org/10.46381/reic.v18i2.347

www.criminologia.net

ISSN: 1696-9219 
refugee or stateless children on the sole basis of their migration status or that of their parents, is a violation of Art. $3 \mathrm{CRC}$, hence strictly prohibited. Consequently, the Committee came to the conclusion that detention cannot be justified solely on the basis of the child being unaccompanied or separated, or on their migratory or residence status, to which end Member States were urged to expeditiously and completely cease the detention of children on the basis of their immigration status $(2005$, para. 61; 2012, para. 32, 78). Nevertheless, according to Art. 6(2) of Directive 2013/32/EU, member States shall ensure that asylum seekers are provided with the opportunity to lodge applications for international protection as soon as possible, thus proving that one is expected to enter the host country irregularly, before following asylum processes.

Hence, for one to be considered as international protection applicant, one must promptly express a fear of suffering serious harm when returned to the country of origin or former habitual residence, as stated under the Practical Handbook for Border Guards Schengen Handbook (2006, para. 10). Immediately after that, Art. 83 of Act 3386 of 2005, as discussed, ceases to exist and the criminalisation of illegal entry for asylum-seeking children is temporarily postponed, ergo the State authorities refrain from prosecution for illegal entry until an official decision on the application for international protection is issued. This means that even if one has entered the Greek territory illegally, one is not considered to violate the provisions of Act 3386 of 2005, for as long one's application for international protection is under examination. Based on that, we can state that one depends entirely on the outcome of the application for international protection, whereas in the meantime, the criminalisation of illegal entry still stands strong.

Reality dictates that during that specific timeframe, minors are subjected to administrative proceedings that resemble the outcome of criminal law processes, thus creating a unique link between Art. 12(2) CRC and the crimmigration debate. Following this premise and despite the wide research with regard to crimmigration (e.g. Van der Woude, Van der Leun and Nijland, 2014), it appears that no question was ever raised among scholars on the criminalisation of migrant minors arriving in Greece, solely based on them irregularly entering the country, mainly because during administrative detention, migrant minors are still

\section{Revista Española de Investigación Criminológica}

Article 1, Volume 18(2) (2020)

https://doi.org/10.46381/reic.v18i2.347

www.criminologia.net

ISSN: 1696-9219 
considered to be placed under a custodial regime of a protective character. Therefore, detention, in this case, is not considered to be an administrative process as stated under Art. 12(2) CRC, which results to children being deprived of the right to express themselves freely and question it accordingly. As a result, crucial questions are formed whether migrant children are or are not provided with the right to be heard when it comes to administrative detention being applied upon them. Unfortunately, the voice of refugee minors in this specific stage of the asylum procedure in Greece remains silenced.

\section{On being voiced in the Belgian asylum procedure}

It is because of complex vulnerabilities of migrant minors, that a children's rights approach is advanced in multiple human rights instruments, namely the CRC under Art. 22, dictating that appropriate protection and humanitarian assistance is to be provided by State Parties to migrant minors, the UN guidelines of the Children's Rights Committee (such as for example General Comment No. 6 on the treatment of unaccompanied and separated children), the EU Directives (such as the EU directive on common procedures for granting and withdrawing international protection) and the case-law of the ECtHR (such as the famous Thabita case) ${ }^{3}$. Accordingly, member States must always take Art. 3 CRC as a primary consideration, with special attention added to the needs of the child, the child's right to family life and deprivation of liberty as a measure of last resort. Not only the decisions and execution of these decisions must be in line with a children's rights approach, but also the procedures leading to those decisions must follow the $\mathrm{CRC}$, and more precisely Art. $12 \mathrm{CRC}$, as discussed. Given that children are possibly limited in the way they can express themselves in the asylum procedure, especially when compared to adults (UNHCR, 2014), asylum processes require certain guarantees, such as the conduction of interviews in a child-appropriate manner, as stipulated under Art. 15(3)(e) of Directive 2013/32/EU.

\footnotetext{
${ }^{3}$ Mubilanzila Mayeka and Kaniki Mitunga v. Belgium, 13178/03, Council of Europe: European Court of Human Rights,
} 12 October 2006.

Revista Española de Investigación Criminológica

Article 1, Volume 18(2) (2020)

https://doi.org/10.46381/reic.v18i2.347

www.criminologia.net

ISSN: 1696-9219 
Nevertheless, a tension exists between child-specific rights and the aim for truthfinding, which is vividly present in the asylum interview. In Belgium, this procedure is performed at the office of the Commissioner-General for Refugees and Stateless Persons $\left(\mathrm{CGRS}^{4}\right)$, where the caseworker, called protection officer, formally hears the applicant and distinguishes the truth from improbabilities and inconsistencies by scrutinizing all relevant elements in the oral testimony of the applicant. Hence, it is of crucial importance that the protection officer protects children's rights, while at the same time, looking for evidence and inconsistencies in a child's story. Asylum seeking minors are heard and interviewed several times and are expected to tell a story in a way that is credible and most likely to result in positive outcomes for their claim. For this reason, Maryns (2014) talks about rehearsed narratives and the fact that the asylum interview can create a paradoxical situation as it is not so much the request for international protection that is thoroughly researched on its credibility, but rather the storytelling-ability of an asylum seeker. According to Maryns, the victims of this system are those whose authentic narrative does make sense but who simply do not get the chance to tell their story (2014, p. 314).

Many people who flee their country, but children especially, are possibly limited in the way they can express themselves in the asylum procedure (UNHCR, 2014). Nevertheless, both under Belgian refugee law and under the Convention, minors undergo the same procedures as adults. Even though children, regardless of their age, fall under the same definitions for refugee or subsidiary protection status, there are some child-specific provisions embedded in both national and international law. More specifically, an asylumofficial needs to take into account the multi-layered vulnerability of minors during the asylum interview (asylum hearing in Dutch), so that the process is adapted to the special needs of minors $^{5}$. In addition, there should be a liberal application of the benefit of the doubt rule in children's claims for protection should there be hesitation regarding the credibility of the child's story, the burden is not on the child to provide proof, but the child should be given

\footnotetext{
${ }^{4}$ https://www.cgra.be/en.

${ }^{5} \mathrm{~KB}$ van 11 juli 2003 tot regeling van de werking van en de rechtspleging voor het Commissariaat-generaal voor de Vluchtelingen en de Staatlozen, BS 27 januari 2004.
}

Revista Española de Investigación Criminológica

Article 1, Volume 18(2) (2020)

https://doi.org/10.46381/reic.v18i2.347

www.criminologia.net

ISSN: 1696-9219 
the benefit of the doubt (UNHCR, 2014). With regard to the latter, Vernimmen \& Reyntjens (2018) analysed the asylum application procedures of UAM in the case-law of the Council for Alien Law Litigation ${ }^{6}$ in Belgium and came to the interesting conclusion that children, no different from adults, are expected to narrate in detail about their route to Belgium, motives to flee and the social and political context in the country of origin. The importance of credibility and consistency of an asylum story seemed to be no different in children's claims, even though a liberal application of the benefit if the doubt rule for children should be implemented (UNHCR, 2019, p. 46). Therefore, questions rise on how children's mental development, maturity and child mentality are considered in daily practice during reception procedures, including asylum interviews and at what point a child's right to be heard risks to become interpreted as the duty to speak up about the migration story.

\section{Conclusion}

In this paper, it was our goal to discuss the application of children's rights in the context of migration, by elaborating on how the voice of the child can be unfolded in different domestic policies and European legal frameworks. By devoting specific attention to reception proceedings in Greece and the administrative processes that follow a child's application for international protection in Belgium, we emphasized on the right of children to effectively participate in all matters affecting them and having their views taken into account. Even though European countries have ratified the $\mathrm{CRC}$, and human- and children's rights instruments are getting more and more sophisticated every day, we have identified several implementation gaps, one of the biggest limitations being that a human rights' narrative goes hand in hand with deep-seated unenforceability issues. Even though protection imperatives are in place, there is a discrepancy between guaranteeing the protection of children's rights and the effective applicability of the CRC in the case of migrant minors, both during reception proceedings, as well as during the asylum interview. On this subject, we concluded

\footnotetext{
${ }^{6}$ This is an independent administrative court in Belgium where an appeal can be made against a decision of the office of the Commissioner General for Refugees and Stateless persons.
}

Revista Española de Investigación Criminológica

Article 1, Volume 18(2) (2020)

https://doi.org/10.46381/reic.v18i2.347

www.criminologia.net

ISSN: 1696-9219 
that Art. 12 CRC depends entirely on each member States' aptness to effectively incorporate the $\mathrm{CRC}$ within its domestic policy. Ultimately, when it comes to children on the migratory pathway, Pisani (2018, p. 177) frames it most adequately: in the case of the illegalized young body - the non-citizen - the 'right to rights' cannot be assumed.

In respect of the Greek context in specific, our analysis raised issues on the problematic relationship between administrative detention for migrant minors and Art. 12 CRC, which currently leads to the voice of migrant minors being practically silenced. Under the premise of Art. 12(2) CRC, children should be provided with the ability to be heard in an unstrained manner, regarding all administrative processes that are applied upon them. A critical examination of this provision would lead to the conclusion that asylum-seeking children should have the right to question detention itself, the latter being a measure of administrative character, as discussed. However, to this day, domestic policy in Greece does not acknowledge that protective custody has practically been replaced by administrative detention, despite the suffering that this entails for children on the migratory pathway. Stemming from this erroneous condition, rights-based research on the applicability of Art. $12 \mathrm{CRC}$ in the Greek legal context is expected, aiming to create an environment where children's voices are heard. With the achievement of the latter, a more effective legal and procedural framework will be established, and the ground will be set for the positive adjustment and integration of all the CRC provisions in the Greek legal context. Such practices will eventually have a positive outcome and impact on decisions being taken in favour of children, whereas detention will cease to be off the radar when it comes to protecting the rights of migrant minors seeking refuge in Europe.

On the other hand, when it comes to children applying for international protection in Belgium and undergoing the hearing procedure that follows, this contribution has raised questions on the importance of narratives and stories being told. Even though child-specific provisions exist in theory, research has shown that the balance between the aim of truthfinding and the aim to protect children's rights in such procedures is not self-evident. Children, just like adults, need to narrate in detail about their asylum story in a way that is plausible and consistent. When children's applications fail, this is often due to a lack of 
credibility. These inquiries raise even more questions; how central are their authentic voices in procedures and how is due weight given to their voice concerning their age, maturity and multi-layered vulnerabilities? What role can silence have in children's claims for asylum? In other words, what if being voiced in asylum procedures poses a problem for children?

To answer these questions, we have pointed out the need to discover whether realities lived by children who undergo reception and asylum procedures are in line with rights frameworks and how children experience the rights accorded to them. In order to understand the perplexities and contemporary struggles involved, there is a need to enable children to make themselves be heard, not only in the institutional and procedural asylum and immigration context, where narratives of minors end up in official files, but also in academia where the voice of the child is being transformed in a way that is presentable to the outside world. In the light of research that aims to voice participants, this paper focused on the importance to highlight that issues of voice (such as in the example of the asylum hearing) can be present in academic research as well. More specifically, the participant could share a narrative that is economical with the truth as there could still be a worry about the safety in talking to others (Kohli, 2006). As a result, the voice that is being heard by the researcher could then be an institutional voice that is not authentically represented and therefore superficial (Gilligan, 1993, 2004, 2015). We can thus say that giving voice can be sensitive, even if it is an academic or professional who is listening.

Therefore, we argued that voicing needs to be cautiously decomposed, analysed, and even questioned, both in academia and in asylum procedures. When is a voice authentic, and how is a voice being represented both in and outside of academia? To answer questions as such there is a need to have a better - and more in-depth - understanding of narratives, voice and the context in which voices are being produced, heard and reproduced in the complexity that is part of childhood (Hunleth, 2011; Spyrou, 2011). To this end, an important challenge for researchers is to find ways into children's visions of life (Clavering \& McLaughlin, 2010, p. 607), while giving children's voices a central place in research. After all, we cannot easily presume that (young) children always have a clear vision with regards to complex subjects such as asylum and migration procedures, for which reason, the researcher should also be

Revista Española de Investigación Criminológica

Article 1, Volume 18(2) (2020)

https://doi.org/10.46381/reic.v18i2.347

www.criminologia.net

ISSN: 1696-9219 
able to take on an informing and facilitating role and provide guidance in the exercise of the CRC rights (Lundy \& McEvoy, 2012). It is obvious that in order to produce knowledge, we depend heavily on the stance taken on the relationship between knowledge and knowledge producer (Bauwens, Kennis \& Bauwens, 2013).

This relationship needs to be made explicit as it inherently influences methodological frameworks and raises questions on the relationship between participant and researcher, the authenticity of voice and the effects on the representation of voice. James (2007) indicates that giving children a voice in research is not limited to the narrative a child produces, but rather to the way a voice gives us a unique stance on the social world from the perspective of a child. In other words, children's voices inherently contribute to theory building in our social world. Hence, contemporary research must aim at facilitating asylum-seeking children in raising their voice, so that we gain greater awareness on their experiences throughout all stages of the asylum process. By assessing whether or not the CRC provisions and Art. 12 in specific are applied in a way that protects the rights of children on the migratory pathway, we will be able to explore how these minors experience asylum procedures upon arrival in the host country and further examine the humanitarian aspects of the tension between human rights and immigration policing. 


\section{References}

Aas, K. F. (2011). 'Crimmigrant' bodies and bona fide travellers. Surveillance, citizenship and global governance. Theoretical Criminology, 15(3), 331-346. doi:10.1177/1362480610396643.

Aliverti, A. (2012). Making people criminal: The role of the criminal law in immigration enforcement. Theoretical Criminology, 16(4), 417-434. doi:10.1177/1362480612449779.

Barker, J., \& Smith, F. (2001). Power, positionality and practicality: Carrying out fieldwork with children. Ethics, Place \& Environment, 4, 142-147. doi:10.1080/713665949.

Bauwens, T., Kennis, P., \& Bauwens, A. (2013). Paradigms. Waving the flag or Flagging the Wave? In K. Beyens, J. Christiaens, B. Claes, S. De Ridder, H. Tournel, \& H. Turbex (Eds.), The Pains of Doing Criminological Research (pp. 23-37). Brussels: VUBPress.

Beazley, H., Bessell, S., Ennew, J., \& Waterson, R. (2010). The right to be properly researched: research with children in a messy, real world. Children's Geographies, 7(4), 365-378. doi:10.1080/14733280903234428.

Bhabha, J. (2001). Minors or Aliens? Inconsistent State Intervention and Separated Child Asylum-Seekers. European Journal of Migration and Law, 3(3-4), 283-314. doi:10.1163/15718160120959276.

Bhabha, J. (2014). Child Migration \& Human Rights in a Global Age. Princeton: Princeton University Press.

Bosworth, M. (2014). Inside Immigration Detention. Oxford: Oxford University Press.

Christensen, P. (2004). Children's participation in ethnographic research: Issues of power and representation. Children and Society, 18(2), 165-176. doi:10.1002/chi.823.

Clacherty, G., \& Donald, D. (2007). Child participation in research: Reflections on ethical challenges in the southern African context. African Journal of AIDS Research, 6(2), 147156. doi:10.2989/16085900709490409.

Clavering, E., \& McLaughlin, J. (2010). Children's participation in health research: from objects to agents? Child: Care, Health and Development, 36, 603-611. doi:10.1111/j.1365-2214.2010.01094.x.

Derluyn, I. \& Broekaert, E. (2008). Unaccompanied Refugee Children and Adolescents: The Glaring Contrast between a Legal and a Psychological Perspective. International Journal of Law and Psychiatry 31(4), 319-330. doi:10.1016/j.ijlp.2008.06.006.

European Union: Council of the European Union (2006). Commission Recommendation establishing a common 'Practical Handbook for Border Guards (Schengen Handbook)' to be used by Member States' competent authorities when carrying out the border control of persons, $\quad 9 \quad$ November, $15010 / 06$. http://register.consilium.europa.eu/doc/srv?l=EN\&f=ST\%2015010\%202006\%20INIT.

European Union: Charter of Fundamental Rights of the European Union (2012). 26 October, 2012/C 326/02. http://www.refworld.org/docid/3ae6b3b70.html.

European Union: Council of the European Union (2013). Directive 2013/32/EU of the European Parliament and of the Council of 26 June 2013 on common procedures for granting and withdrawing international protection (recast), 29 June, OJ L. 180/60 -180/95. https://www.refworld.org/docid/51d29b224.html.

Revista Española de Investigación Criminológica

Article 1, Volume 18(2) (2020)

https://doi.org/10.46381/reic.v18i2.347

www.criminologia.net

ISSN: 1696-9219 
Galante, V. (2014). Greece's Not-So-Warm Welcome to Unaccompanied Minors: Reforming EU Law to Prevent the Illegal Treatment of Migrant Children in Greece. Brooklyn Journal of International Law 39(2), 745-791. Available at: https://brooklynworks.brooklaw.edu/bjil/vol39/iss2/5/.

Gallagher, M. (2008). "Power is not an evil": Rethinking power in participatory methods. Children's Geographies, 6(2), 137-150. doi:10.1080/14733280801963045.

Gilligan, C. (1993). In a different Voice. Psychological Theory and Women's Development. Cambridge: Harvard University Press.

Gilligan, C. (2004). Knowing and not knowing: reflections on manhood. Psychotherapy and Politics International, 2(2), 99-114. doi:10.1002/ppi.157.

Gilligan, C. (2015). The Listening Guide method of psychological inquiry. Qualitative Psychology, 2(1), 69-77. doi:10.1037/qup0000023.

Goodman, J. H. (2004). Coping with trauma and hardship among unaccompanied refugee youth from Sudan. Qualitative Health Research 14(9), 1177-1196. doi: 10.1177/1049732304265923.

Greece: Act No. 3386/2005 Codification of Legislation on the Entry, Residence and Social Integration of Third Country Nationals on Greek Territory [Greece]. http://www.refworld.org/docid/4c5270962.html.

Greek Ombudsman Department of Children's Rights (2003-2011) Parallel Report to the UN Committee on the Rights of the Child - Findings and recommendations of the Independent Authority 'the Greek Ombudsman' on the implementation of Children's Rights in Greece. https://www.synigoros.gr/? $\mathrm{i}=$ childrens-rights.en.recentinterventions.82331.

Greek Ombudsman Department of Children's Rights (2016) Intervention of the Greek Ombudsman regarding unaccompanied minor refugees and migrants. http://bit.ly/2jwBDwm.

Gündogdu, A. (2015). Rightlessness in an age of rights. Hannah Arendt and the contemporary struggles of migrants. Oxford: Oxford Univerisity Press

Hancilova, B., \& Knauder, B. (2011). Unaccompanied Minor Asylum-seekers: Overview of Protection, Assistance and Promising Practices. Budapest.

Hart, R. (1997). Children's Participation: The Theory and Practice of Involving Young Citizens in Community Development and Environmental Care. New York: Unicef/Earthscan Publications.

Hodgkin, R. \& Newell, P. (2007). Implementation Handbook for the Convention on the Rights of the Child. New York, UNICEF. Available at: https://www.unicef.org/publications/index 43110.html.

Holland, S., Renold, E., Ross, N. J., \& Hillman, A. (2010). Power, agency and participatory agendas: A critical exploration of young people's engagement in participative qualitative research. Childhood, 17(3), 360-375. doi:10.1177/0907568210369310.

Hood, S., Mayall, B., \& Oliver, S. (1999). Critical issues in social research: Power and prejudice. Buckingham: Open University Press.

Hunleth, J. (2011). Beyond on or with: Questioning power dynamics and knowledge production in "child-oriented" research methodology. Childhood, 18(1), 81-93. doi: $10.1177 / 0907568210371234$.

Revista Española de Investigación Criminológica

Article 1, Volume 18(2) (2020)

https://doi.org/10.46381/reic.v18i2.347

www.criminologia.net

ISSN: 1696-9219 
James, A., Jenks, C., \& Prout, A. (1998). Theorizing childhood. Cambridge: Polity Press.

James, A, \& Prout, A. (2015). Constructing and reconstructing childhood: contemporary issues in the sociological study of childhood. New York: Routledge.

James, A. (2007). Giving Voice to Children's Voices: Practices and Problems, Pitfalls and Potentials. American Anthropologist, 109(2), 261-272. doi: 10.1525/AA.2007.109.2.261.

Kellett, M. (2012). Child-led research from inception to reception: methodological innovation and evolution issues. Communication Management Quarterly, 24(2012), 526. doi: $10.5937 /$ comman $1224005 \mathrm{~K}$.

Kellett, M., Forrest, R., \& Ward, S. (2004). 'Just Teach Us The Skills Please, We'll Do The Rest': Empowering Ten-Year-Olds as Active Researchers. Children and Society, 18(February), 329-343. doi:10.1002/chi.807.

Kohli, R. K. S. (2006). The sound of silence: Listening to what unaccompanied asylumseeking children say and do not say. British Journal of Social Work, 36(5), 707-721. doi:10.1093/bjsw/bch305.

Krappmann, L. (2010). The weight of the child's view (Article 12 of the Convention on the Rights of the Child). International Journal of Children's Rights 18(4), 501-513. doi: $10.1163 / 157181810 X 528021$.

Landsdown, G. (1994). Children's Rights. In B. Mayall (Ed.), Children's Childhoods: Observed and Experienced (pp. 33-44). London: Falmer Press.

Lidén, G. \& Nyhlén, J. (2016). Structure and Agency in Swedish Municipalities' Reception of Unaccompanied Minors. Journal of Refugee Studies 29(1), 39-59. doi: $10.1093 / \mathrm{jrs} / \mathrm{fev} 015$.

Lundy, L. (2007). 'Voice' is not enough: conceptualising Article 12 of the United Nations Convention on the Rights of the Child. British Educational Research Journal, 33(6), 927942. doi:10.1080/01411920701657033.

Lundy, L., \& McEvoy, L. (2012). Children's rights and research processes: Assisting children to (in)formed views. Childhood, 19(1), 129-144. doi: $10.1177 / 0907568211409078$.

Lundy, L., McEvoy, L., \& Byrne, B. (2011). Working With Young Children as CoResearchers: An Approach Informed by the United Nations Convention on the Rights of the Child. Early Education \& Development, 22(5), 714-736. doi:10.1080/10409289.2011.596463.

Maryns, K. (2014). The Asylum Speaker. Language in the Belgian Asylum Procedure. London: Routledge Taylor \& Francis Group.

McCafferty, P. (2017). Implementing Article 12 of the United Nations Convention on the Rights of the Child in Child Protection Decision-Making: A Critical Analysis of the Challenges and Opportunities for Social Work. Child Care in Practice 23(4), 327-341. doi:10.1080/13575279.2016.1264368.

Morrow, V., \& Richards, M. (1996). The ethics of social research with children: An overview. Children and Society, 10(2), 90-105. doi:10.1111/j.10990860.1996.tb00461.x. 
Munford, R., \& Sanders, J. (2004). Recruiting diverse groups of young people to research. Agency and empowerment in the Consent Process. Qualitaitive Social Work, 3(4), 469482. doi: $10.1177 / 1473325004048026$.

Oh, S. A. (2012). Photofriend: Creating visual ethnography with refugee children. Area, 44(3), 282-288. doi:10.1111/j.1475-4762.2012.01111.x.

Pakes, F. (2013). Globalisation and the challenge to criminology. Globalisation and the Challenge to Criminology. doi:10.4324/9780203436851.

Papadopoulos, I. \& Pycroft, A. (2019). Detention as protective custody for Unaccompanied Migrant Minors: A social and legal policy overview of the Greek framework on conditions of detention, under the scope of the UNCRC. In E.M. Guzik-Makaruk \& E.W. Pływaczewski (eds.), Current Problems of the Penal Law and Criminology (p. 581-595). C. H. Beck, Warsaw.

Papadopoulos, I. (2019) How protective is custody for unaccompanied minors in Greece? Protecting children's rights within detention. In Klaassen, M., Rap, S., Rodrigues, P. and Liefaard, T. (eds.), Safeguarding Children's Rights in Immigration Law (p. 179-194). Cambridge: Intersentia.

Parkes, A. (2013). Children and International Human Rights Law: The Right of the Child to be Heard. London: Routledge.

Pisani, M. (2018). Illegal young bodies and the failings of liberal democracy. Some reflections on the European Union's "refugee crisis" and its implications for juvenile justice. In B. Goldson (Ed.), Juvenile Justice in Europe. Past, Present and Future (p. 284). London: Routledge.

Powell, M. A., Fitzgerald, R. M., Taylor, N., \& Graham, A. (2012). International literature review: ethical issues in undertaking research with children and young people. Childwatch International Research Network, 25.

Powell, M. A., \& Smith, A. B. (2006). Ethical guidelines for research with children: A review of current research ethics documentation in New Zealand. Kotuitui: New Zealand Journal of Social Sciences Online, 1(2), 125-138. doi:10.1080/1177083X.2006.9522415.

Rap, S. (2019). The Right to Effective Participation of Refugee and Migrant Children: A Critical Children's Rights Perspective, Working Paper Series W-2019/3. United Nations University, Institute on Comparative Regional Integration Studies. Available at: http://cris.unu.edu/sites/cris.unu.edu/files/W-2019-3.pdf

Spyrou, S. (2011). The limits of children's voices: From authenticity to critical, reflexive representation. Childhood, 18(1), 1-15. doi:10.1177/0907568210387834.

Stumpf, J. (2006). The Crimmigration Crisis : Immigrants , Crime , and Sovereign Power. American University Law Review, 56(2), 367-419. Available at: http://digitalcommons.wcl.american.edu/aulr.

Thomas, N., \& O'Kane, C. (1998). The ethics of participatory research with children. Children and Society, 12(5), 336-348. doi:10.1111/j.1099-0860.1998.tb00090.x.

Thommessen, S., Laghi, F., Cerrone, C., Baiocco, R. \& Todd, B. K. (2013). Internalizing and externalizing symptoms among unaccompanied refugee and Italian adolescents. Children and Youth Services Review 35(1), 7-10. doi:10.1016/j.childyouth.2012.10.007.

Revista Española de Investigación Criminológica

Article 1, Volume 18(2) (2020)

https://doi.org/10.46381/reic.v18i2.347

www.criminologia.net

ISSN: 1696-9219 
Thommessen, S., Corcoran, P. \& Todd, B. K. (2015). Experiences of arriving to Sweden as an unaccompanied asylum-seeking minor from Afghanistan: An interpretative phenomenological analysis. Psychology of Violence 5(4): 374-383. doi:10.1037/a0038842.

UN Committee on the Rights of the Child (2005) General Comment No. 6: Treatment of Unaccompanied and Separated Children Outside their Country of Origin, 1 September, CRC/GC/2005/6. http://www.refworld.org/docid/42dd174b4.html.

UN Committee on the Rights of the Child (2009) General Comment No. 12: The right of the child to be heard, 20 July, http://www.refworld.org/docid/4ae562c52.html.

UN Committee on the Rights of the Child (2012) Committee on the Rights of the Child, Report of the 2012 Day of General Discussion on the Rights of All Children in the Context of International Migration, 28 September. https://www.refworld.org/docid/51 efb6fa4.html.

UN Committee on the Protection of the Rights of All Migrant Workers and Members of Their Families (2017) Joint General Comment No. 4 (2017) of the Committee on the Protection of the Rights of All Migrant Workers and Members of Their Families and No. 23 (2017) of the Committee on the Rights of the Child on State obligations regarding the human rights of children in the context of international migration in countries of origin, transit, destination and return, 16 November, CMW/C/GC/4-CRC/C/GC/23. https://www.refworld.org/docid/5a12942a2b.html.

UN General Assembly (1951) Convention Relating to the Status of Refugees. United Nations, Treaty Series, 189: 137. http://www.refworld.org/docid/3be01b964.html.

UN General Assembly (1967), Protocol Relating to the Status of Refugees. United Nations, Treaty Series, 606: 267. https://www.refworld.org/docid/3ae6b3ae4.html.

UN General Assembly (1989), Convention on the Rights of the Child. United Nations, Treaty Series, 1577: 3. http://www.refworld.org/docid/3ae6b38f0.html.

UN General Assembly (1996) Impact of armed conflict on children. Note by the SecretaryGeneral, A/51/306. http://www.refworld.org/docid/3b00f2d30.html.

UN High Commissioner for Refugees (2013) Global Trends. http://www.unhcr.org/statistics/country/51bacb0f9/unhcr-global-trends-2012.html.

UN High Commissioner for Refugees (2014), The Heart of the Matter - Assessing Credibility when Children Apply for Asylum in the European Union. https://www.refworld.org/docid/55014f434.html.

UN High Commissioner for Refugees (2019), Handbook on Procedures and Criteria for Determining Refugee Status and Guidelines on International Protection Under the 1951 Convention and the 1967 Protocol Relating to the Status of Refugees, HCR/1P/4/ENG/REV, 4. https://www.refworld.org/docid/5cb474b27.html.

UN Human Rights Council, Report of the Working Group on Arbitrary Detention (2015) United Nations Basic Principles and Guidelines on Remedies and Procedures on the Right of Anyone Deprived of Their Liberty to Bring Proceedings Before a Court, A/HRC/30/37. https://www.refworld.org/docid/55d2f44a4.html.

\section{Revista Española de Investigación Criminológica}

Article 1, Volume 18(2) (2020)

https://doi.org/10.46381/reic.v18i2.347

www.criminologia.net

ISSN: 1696-9219 
Vernimmen, J. \& Reyntjens, L. (2018). De erkenning en toetsing van kindspecifieke vervolgingsgronden in de asielprocedure van niet-begeleide minderjarige vreemdelingen. In Rechten van niet-begeleide minderjarige vreemdelingen in België (pp. 199-219). die Keure.

Vervliet, M., Rousseau, C., Broekaert, E. \& Derluyn, I. (2015). Multilayered Ethics in Research Involving Unaccompanied Refugee Minors. Journal of Refugee Studies, Oxford University Press 28(4): 468-485. doi:10.1093/jrs/feu039.

Van der Woude, M. A. H., Van der Leun, J. P. \& Nijland, J. A. (2014). Crimmigration in the Netherlands. Law and Social Inquiry 39(3): 560-579. doi:10.1111/1si.12078.

\section{Funding}

The research of Marijke Van Buggenhout is financed by the Research Foundation - Flanders (FWO) under grant number G078419N.

Ioannis Papadopoulos (LL.B.; LL.M.) is a doctoral candidate at the Institute of Criminal Justice Studies, University of Portsmouth, UK. His research addresses the implementation of the UNCRC within domestic policy in the EU, with a particular emphasis added to the situation of Greece concerning issues of detention and juvenile justice with respect to unaccompanied minors. Since 2016 he has been collaborating with International and Greek humanitarian organisations, providing legal counselling on asylum procedures to migrant children. He is member of the 'ESC Working Group on Immigration, Crime and Citizenship' and co-chair of the 'Qualitative Research Methodologies and Epistemologies Working Group (WG-QRME)', as part of the European Society of Criminology.

iD

https://orcid.org/0000-0001-7664-5479

Marijke Van Buggenhout is a member of the Voicing Youth at Social Risk Research group (VOICe) and the Crime and Society Research group (CRiS) at Vrije Universiteit Brussel. As a researcher she is interested in how experiences and voices of children in vulnerable situations can receive a more active and central place in academic and societal debates. Her $\mathrm{PhD}$ research provides insight into how asylum procedures with children/young adults are conducted in practice and includes experiences of young asylum seekers who are subjected to these procedures.

iD

https://orcid.org/0000-0002-3532-0827 